\title{
Parenchymal asbestosis can lead to lung cancer within a short time frame: more frequent follow-up surveillance is needed than currently recommended
}

\author{
V Murlidhar
}

National Institute of Epidemiology, Indian Council of Medical Research (ICMR), Chennai, India

\section{Correspondence to} V Murlidhar,

murlidharv@gmail.com

Accepted 22 March 2015

\section{DESCRIPTION}

A 65-year-old non-smoker and former worker of the Hindustan Composites Asbestos factory, Mumbai, was screened at the Occupational Health and Safety Centre, Mumbai, which has helped diagnose and compensate occupational diseases including asbestosis since $1988 .{ }^{1}$ He had 28 years of exposure to asbestos as a worker in the textileplating department, a dusty section of the factory. He was asymptomatic and had no relevant clinical signs. His chest X-ray showed evidence of asbestosis: ILO (International Labour Organization) grading s/s; 1/0 (figure 1). Nine months later, he developed dyspnoea and a repeat X-ray (figure 2) and a positron emission tomography (PET)-CT (figure 3) showed evidence of lung cancer in the hilar region of the left lung infiltrating into the left bronchus and the

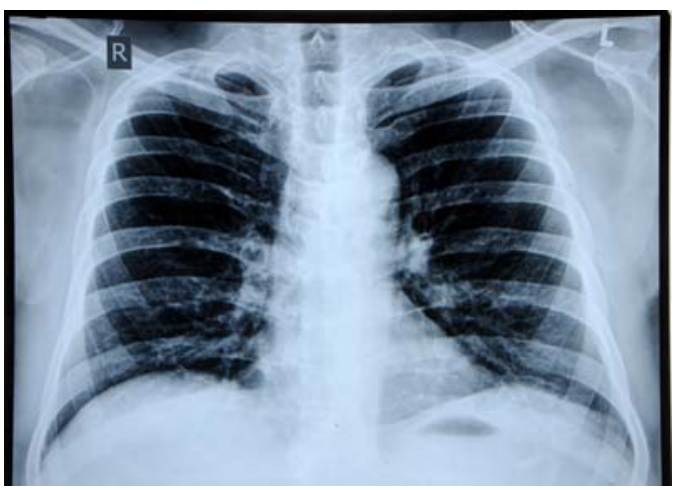

Figure 1 Chest posteroanterior view showing parenchymal asbestosis mainly in the lower lobes (ILO (International Labour Organization) grading s/s, 1/0).

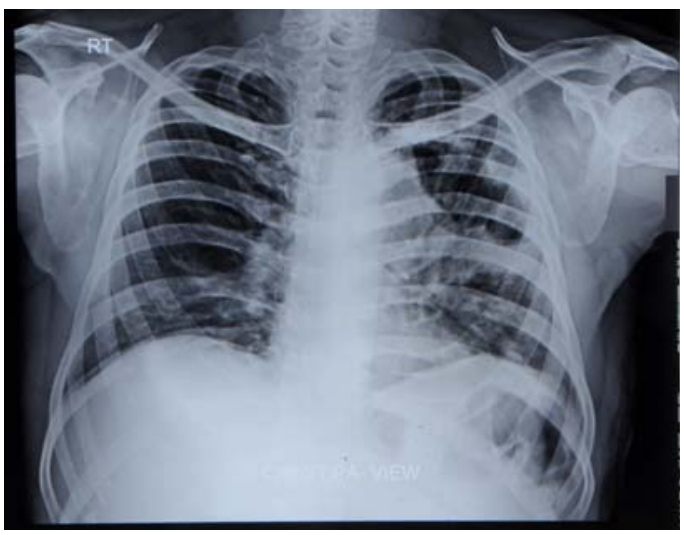

Figure 2 Chest PA view shows left hilar mass suggestive of malignancy of the left lung and asbestosis (ILO (International Labour Organization) grading s/s, 1/0).

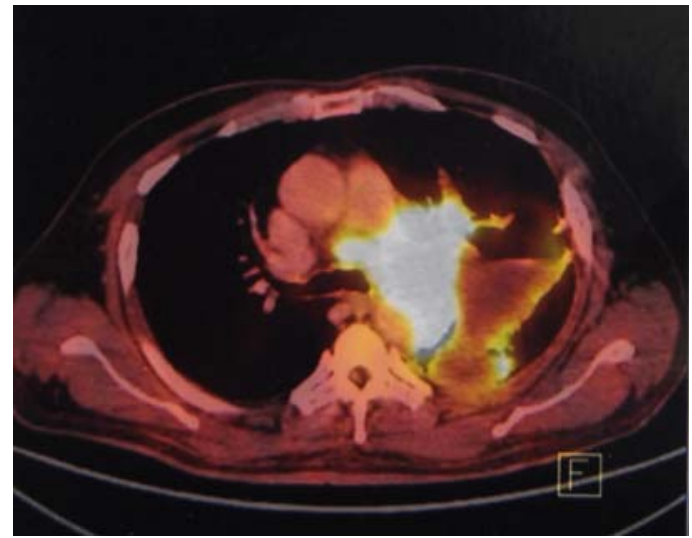

Figure 3 Positron emission tomography CT scan showing a large mass (white) totally blocking the left bronchus and infiltrating onto the root of the pulmonary artery.

pulmonary artery. He received palliative care before he died 4 months later. He was compensated for both asbestosis and lung cancer.

Although parenchymal asbestosis can lead to lung cancer, there is no direct relationship between pulmonary fibrosis and the subsequent development of lung cancer, nor is it possible to predict the time frame as to the development of lung cancer. ${ }^{2}$ The critical issue is the frequency of radiological screening among former workers so that lung cancer can be detected early leading to a better prognosis. A recent consensus document suggested 3-5 yearly chest X-rays as a follow-up surveillance for former asbestos-exposed workers. ${ }^{3}$ The case clearly shows that the suggested frequency of follow-up surveillance is insufficient to detect asbestos-related lung cancer at a curable stage.

\section{Learning points}

- Lung cancer can rapidly develop in workers formerly exposed to asbestos within a short time frame of less than 1 year.

- Lung cancer screening of asbestosis-affected workers (presently working or ex-employees) should be performed at much more frequent intervals than the current recommendation of 3-5 years' intervals.

Acknowledgements I wish to thank Sowmya Sivakumar for proof reading.

Competing interests None declared. 


\section{Images in...}

Patient consent Obtained.

Provenance and peer review Not commissioned; externally peer reviewed.

\section{REFERENCES}

1 Murlidhar V, Kanhere V. Asbestosis in an asbestos composite mill at Mumbai: a prevalence study. Environ Health 2005;4:24.
2 Henderson DW, Rodelsperger K, Woitowitz HJ, et al. After Helsinki: a multidisciplinary review of the relationship between asbestos exposure and lung cancer, with emphasis on studies published during 1997-2004. Pathology 2004;36:517-50.

3 Wolff $H$, Vehmas T, Oksa P, et al. Asbestos, asbestosis, and cancer, the Helsinki criteria for diagnosis and attribution 2014: recommendations. Scand J Work Environ Health 2015;41:5-15.

Copyright 2015 BMJ Publishing Group. All rights reserved. For permission to reuse any of this content visit http://group.bmj.com/group/rights-licensing/permissions.

BMJ Case Report Fellows may re-use this article for personal use and teaching without any further permission.

Become a Fellow of BMJ Case Reports today and you can:

- Submit as many cases as you like

- Enjoy fast sympathetic peer review and rapid publication of accepted articles

- Access all the published articles

- Re-use any of the published material for personal use and teaching without further permission

For information on Institutional Fellowships contact consortiasales@bmjgroup.com

Visit casereports.bmj.com for more articles like this and to become a Fellow 